and test conditions of radionuclide imaging devices, Part 2: Single photon emission computed tomo. graphs.

- Draft 1st edition of IEC $1675-3$ : Characteristics and test conditions of radionuclide imaging devices, Part 3: Gamma camera based wholebody imaging system.

の審議依頼があり，前回 S文書で回答した内容が無視さ れているので, 再度コメントを提出した。(福喜多博義)

\section{8 線量計班}

1. 1993年に提案されたドキュメントが，各国の意見を 受けた上で修正され, Draft 2nd edition of IEC 731: Medical electrical equipment-Dosimeters with ionization chambers as used in radiotherapy として再提案さ れたのでこれについての審議を行った，細かな点につ いて，いくつかのコメントを付しただけで，ほほ問題な いものとして了承した。

2. Draft 1st Edition of IEC 1674: Medical electrical equipment-Dosemeters with ionization chambers and/or semi-conductor detectors as used in X-ray diagnostic imaging.について審議した。これは乳房写真 やCT を含んだ $150 \mathrm{keV}$ 以下の光子によるX線画像用の 線量計を対象にしているものである. Air Kerma および Air Kerma Langthの定義から測定方法, 測定パラメー 夕の許容誤差範囲等々を呈示している。

3. Draft 2nd Edition of IEC 601-2-9: Particular requirements for the safety of patient contact dosemeters used in radiotheapy with electrically con. nected radiation detectors.についても審議したが，いず れもいくつかのコメントを付しただけで，特記すべき問 題点はなく回答を終えた。

（津田政行）

\section{$4.9 \mathrm{X}$ 線防護班}

IEC (International Electrotechnical Commission) より1995年 万月付けで送付された，IEC 1331 Protective devices against diagnostic medical $\mathrm{X}$-radiation-Part 3: Protcctive clothing (諮断用X線に対する防護用具 Part 3：防護衣）の文書審議を行った。

審議内容については次のごとくである。

適用範用と目的，引用規格，用語，総則，防護エプロ ン，防護スカート，防護手袋，生殖せん防護エプロン， 陰囊シールド，卵巣シールド，シャドーシールド等であ り，それぞれの防護具について(1)デザイン(2)材料(3)寸法 (4)表示(5)適合の表示等について, 文章内容を対応する, JIS Z 4830 (患者用X線防護衣)，JIS-Z-4803（X線防謢 前掛)，JIS-Z-4802（X線防護手袋），JIS-Z-4806 (診察 用X線防護つい立）を参考に現状の使用状況を考虑し審
議した。 IEC に対する要望点が 2 か所あり第 1 は，防護

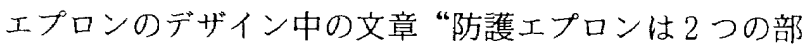
分, ベストとスカート，加構成されてもよい”に(ベ ストとスカートの重なり部分は，充分にカバーされねば ならない）と補足説明をしたほうがよい。第 2 は，防護 スカートの文章“防護スカートは術者の生殖せん防護を 第 1 の目的とする”の使用目的は（単体使用加防護エプ ロンとの併用かを明記する，また単体使用ならば生殖線 以外の組織の防護が問題であるし，また併用使用ならば 吸収線量当量は $0.5 \mathrm{mmPb}$ ではなく $0.25 \mathrm{mmPb}$ で充分 である.）の 2 点を当委員会として IECに回答すること とし，1995年 7 月15日までに送付した。

（伊藤敏夫）

\subsection{0 品質保証班}

使用者側における画像診断部門のQA 関係で次の文 書がIEC Techinical Reportとして正式に発刊された。 IEC 1223-1（93-07）画像診断部門での QA 総則 1223-2-1 (93-07）フイルム現像機の不変性試験 1223-2-2（93-07）フイルム，X線增感紙-カセッテ密着 性の不変性試験

1223-2-3（93-07）暗室安全光条件の不変性試験

1223-2-4（94-03）ハードコピイカメラ（イメージャ等） の不変性試験

1223-2-5（94-03）画像表示モ二夕類の不変性試験

1223-2-6 (94-04）CT 装置の不変性試験

この内, 品質保証委員会では, QA 総則から暗室安全光 条件までを和訳した。引き続き IEC 1223-2 シリーズの 和訳を進める予定である。

(山田和美)

\subsection{1 感光材料班}

この珠は, 写真感光材料工業会が主催し, 構成メンバ 一は日本放射線技術学会 3 名, 日本放射線機器工業会, 富士写真フィルム, コニカより成る. ISO/TC42/WG3 国 内合同会議という名称で開催されており，今までに2 回 会議があり，書類での意見が 1 回求められた.ISO/ $\mathrm{TC} 42 / \mathrm{WG} 3$ 日本委員は犬井正男氏（コニカ，元千葉 大).

1. 第 1 回は, ISO/DIS 9236-1.2: 医療用X線フィルム のセンシトメトリー, 第 1 部：特性曲線の形, ISO スピ ード及び ISO 平均階調度の求め方（Item 153. I 4295131)

日本としては, ISO スピードの分類について, 許容値 との関連で細かすぎると反対することになり後H反対投 票がなされた。反対は 3 国であった。

2. 第 2 回は, Working Dralt No. 1：医療用X線スク リーン・フィルムシステムの両像特性, 第 2 部：変調伝 達関数（MTF）の測定方法（Item XXX, 42-95196）

MTFが加わったために，タイトルが変更になった。日 